UNDERGRADUATE RESEARCH IN NATURAL AND CLINICAL SCIENCE AND TECHNOLOGY (URNCST) JOURNAL Read more URNCST Journal articles and submit your own today at: https://www.urncst.com

\title{
Quantitative Analysis of Ra-226 Biomagnification near Fracking Sites: A Research Protocol
}

Saranya Naraentheraraja, BSc Student [1]*, Bhairavei Gnanamanogaran, BSc Student [1], Paras Kapoor, BSc Student [1], Nayha Eijaz, BSc Student [2]*

[1] Department of Psychology, University of Toronto Scarborough, Toronto, Ontario, Canada M1E4Y3

[2] Department of Physical \& Environmental Sciences, University of Toronto Scarborough, Toronto, Ontario, Canada M1E4Y3

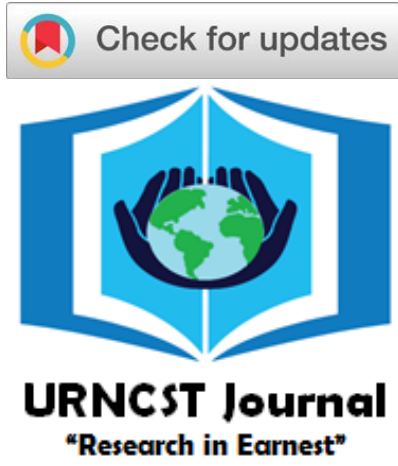

*Corresponding Authors: saranya.naraentheraraja@mail.utoronto.ca, nayha.eijaz@mail.utoronto.ca

\begin{abstract}
Hydraulic fracturing is a controversial method of natural gas extraction that uses high pressure water to release natural gas. Although research has been conducted on the environmental impact of fracking, toxicological and geological research concerning naturally occurring radioactive materials (NORMs) has been scarce. Radionuclides are known to bioaccumulate in the environment and can have toxic effects on humans. This study aims to examine the extent of biomagnification of radium226 from fracking sites to local water (lakes) and agriculture (farmland, livestock pastures). Water samples from areas near fracking sites and homogenized samples of soil and crops will be analyzed by gamma spectroscopy. The data set is expected to be non-normal, therefore, the Mann-Whitney U-test will be used to compare samples between fracking and non-fracking regions. If NORM contamination is significant, it can then be linked to health impacts in humans by assessing carcinogenic risk. If the results show that there are higher levels of Ra-226 in the water near fracking sites and cattle water compared to the control water, as well as progressively higher levels of Ra-226 contamination throughout trophic levels, it can be concluded that fracking poses a potentially radioactive threat to human health. The results of our proposal may indicate tremendous implications on human health as Ra-226 is a chemical that bioaccumulates. Therefore, the results of our study may demonstrate the detrimental impact of radium through fracking.
\end{abstract}

Keywords: hydraulic fracturing; radium-226; gamma spectroscopy; biomagnification; cancer; agriculture; cattle

\section{Introduction}

Hydraulic fracturing is a process that extracts gas and oil in deep reservoirs such as shale rock [1]. It is performed by injecting fluids (fracking fluids) at great pressures to cause fractures which are held open with proppants such as sand or ceramic beads to allow gas to flow out [1]. In fracking fluids, major chemical constituents include Ra-226, alcohols, aromatic compounds, and various other compounds. In wastewater, major chemical constituents include Ra-226, phenols, calcium carbonates, and various other compounds [1]. Ra-226 is the focus of this proposal because it is highly water soluble, making it easier to return to the surface and thus has a higher potential of affecting human health [2]. The hydraulic fracturing process uses extremely large amounts of water, chemicals, and other fluids. Consequently, significant amounts of wastewater with these chemicals is generated which can lead to environmental contamination [3].

Naturally occurring radioactive materials (NORMs) found in wastewater are a significant environmental issue, yet few studies have been conducted to examine the issue of NORM in shale gas production. Most of the literature focuses exclusively on radium contamination in groundwater. A report released by the United States Environmental Protection Agency (EPA) examined the impact of hydraulic fracturing on radioactivity in groundwater by testing groundwater samples for radium-226 (Ra-226), radium228, and gross alpha and beta radiation [4]. Another study reported that wastewater from a wastewater treatment plant from the Marcellus Shale had Ra-226 concentrations that were 200 times higher than normal levels [5]. Radon and radium emit alpha particles that pose a hazardous threat to human health when inhaled or ingested. Radium emits gamma rays leading to lymphoma, bone cancer, and leukemia. Ra-226 has a half-life of 1600 years, thus trace amounts can exist for a long period of time [4].

There is a shortage in research examining the effects of the biomagnification of radium-226 from crops to cattle to humans near fracking sites. Research has linked hydraulic fracturing sites with high levels of radium in nearby soils [6]. If the radium from these fracking fluids is leaked into groundwater, it may accumulate in crops and other food sources, leading to severe health implications such as cancer in humans. 
UNDERGRADUATE RESEARCH IN NATURAL AND CLINICAL SCIENCE AND TECHNOLOGY (URNCST) JOURNAL Read more URNCST Journal articles and submit your own today at: https://www.urncst.com

Recent research explores the environmental impacts of oil industries on a variety of species. Thomas et al. (2005) found that animals such as moose and cattle around mining sites had high levels of radioactive elements [7]. However, our study plans to determine the radioactive impact of fracking sites on local water and agriculture. Previous research also found that Ra-226 released from mining had transferred through the marine food chain from sediments to water to fish [8]. Based on these findings, we propose to analyze the potential health implications that bioaccumulation of Ra-226 can have in humans by determining the radioactive transfer from bodies of water to soil, crops and cattle (see Figure 1). The objective of this proposal is to determine the difference in levels of Ra-226 within agricultural ecosystems between fracking and control sites to determine potential carcinogenic risk to humans.

\section{Methods}

Study sites and sample collection

The study will determine the impacts of fracking in 2 main locations in the U.S. that have the most contaminated waters as stated by the EPA: Dunn and Bradford counties, located in Wisconsin and Pennsylvania respectively (see Figure 2).

The study will look at 3 farms that are located near each of the 2 fracking sites and compare the results to the farms in states that do not use fracking [1]. Farms located far from fracking industries where fracking is either banned or have yet to pursue fracking are chosen to represent the control groups. The use of the 4 locations will help generalize the findings to other farms where fracking occurs in the U.S., and can increase external validity in order to pursue further research into this topic.

First, for each of the 2 fracking locations, EPA's protocol involves sampling fluid from two production wells and three monitoring wells, which are at the site of fracking sites [1]. The water from these locations will be collected 3 months after fracking.

In addition, water will be obtained from domestic water wells and three surface water locations, such as lakes and rivers near fracking sites [1]. The water from domestic wells will be sampled three months after fracking occurs from the Pennsylvania and Killdeer Aquifers, and from control sites that have not been contaminated by fracking [1].

Next, forage grass (cattle feed) samples from 5 farms located in both control and fracking regions will be obtained to determine levels of Ra-226 biomagnified from absorption of ground water.

Feces from 5 male cattle will be collected from each of the farms near the control and fracking sites.

\section{Radioactive analysis}

The radium concentrations (Ra-226 radioactive decay) within collected wastewater samples will be analyzed by using Maxwell's (2016) rapid method, which uses gamma spectrometry. Maxwell's method demonstrates high accuracy by eliminating other elements, such as calcium, barium, strontium, magnesium and sodium to allow for easy and accurate detection of Ra-226 [9].

Polyethylene tubing will be connected to the sampling port of domestic wells, and the other end of the tubing will be connected to a flow cell equipped with a YSI 5600 multi-parameter probe [1]. The well will be purged for 20 minutes, after which the samples will be collected and analyzed using gamma spectroscopy [9].

The forage grass (cattle feed) samples will be filtered and homogenized for analysis with alpha spectroscopy [1].

The feces will be analyzed with alpha spectroscopy to determine the amount of that is present in the cows that are slaughtered for human consumption [10].

\section{$\underline{\text { Statistical analysis }}$}

After obtaining concentrations of Ra-226 in all samples, a Lifetime Carcinogenic Risk Assessment will be used to determine the potential lifetime risk caused by overall exposure to radionuclides irrespective of the body part.

\section{Results}

Radioactive Analysis

Prior research found a significant increase in the concentration of radionuclides in meat from contaminated areas [7]. Therefore, based on prior research by the EPA, water from aquifers located near fracking sites that feed into domestic wells would present higher concentrations of radium compared to control areas [1]. Farmers rely on these aquifers for crops and cattle, and can potentially spread NORMs to agricultural products [1]. The expected findings include significantly higher radionuclides in grass from farms located near fracking sites active 3 months ago compared to control areas. It is expected that the feces of cows from farms near fracking sites have significantly greater concentrations of Radium-226.

\section{Bioaccumulation Potential}

The levels of Ra-226 should increase across each trophic level (from crops to cattle) and should indicate high potential in case of human consumption.

\section{Statistical Analysis}

If the resulting value is less than $1 \times 10^{-6}$, the cancer risk of Ra-226 found in the analyzed samples are considered can be seen as negligible [8]. If, however, the value is above $1 \times 10^{-4}$, the carcinogenic risk is considered to be large and is in need of remediation $[8,11]$.

The data set is most likely expected to be non-normal, therefore statistical analysis will be performed using the Mann-Whitney U-Test to compare samples from fracking and non-fracking regions.

Health Impacts of Radium-226

The lifetime carcinogenic risk assessment can be calcu- 


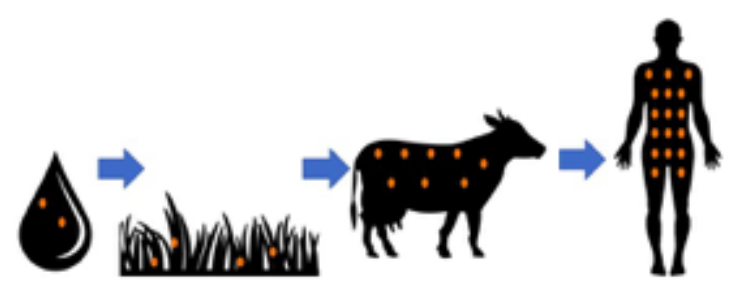

Figure 1: Illustration of the biomagnification of Ra-226 from water, to soil to cattle and to humans.

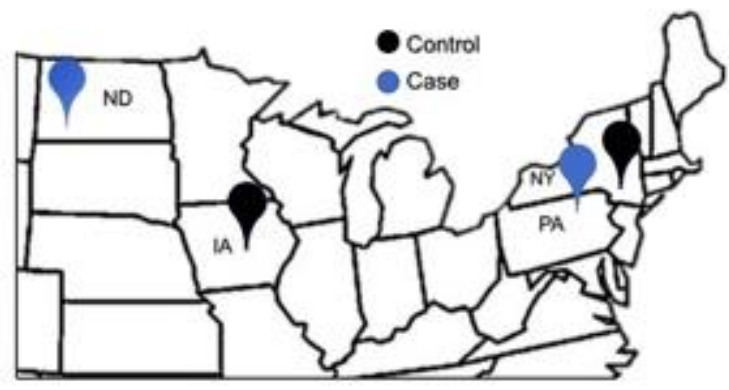

Figure 2: Location of farms within control regions and fracking well pads.

lated for the water obtained from domestic wells and the feces from the cattle. The likelihood obtained from the feces samples represents the likelihood of developing cancer previous literature, the lifetime carcinogenic risk assessment would be high for water samples and feces samples from fracking sites.

\section{Discussion}

Our exploratory research design is proposed to determine the biomagnifying effects of Ra-226, a byproduct of hydraulic fracturing, on soil, crops and humans. To quantify the levels of Ra-226, samples were taken from each trophic level, homogenized and analyzed. In accordance with our hypothesis, if the results depict higher levels of Ra-226 in the water and cattle waste than in the controls, as well as progressively higher levels of Ra-226 contamination throughout the trophic levels, it can be concluded that hydraulic fracturing does in fact contaminate the surrounding areas. If samples collected from areas surrounding fracking sites, indicate a higher chance of carcinogenic risk, it can be deduced that fracking presents radioactive threat to human health.

The potential limitations include the impact that the distance of farms from the fracking site can have on the levels of radium in samples from agriculture and livestock, and how areas exposed to other sources of radioactive elements such as other oil drilling methods would have more radioactive exposure. Another limitation is the differences in farming practices. Depending on the fertilizers used for the crops and what supplements and injections are given to the cattle that may affect the levels of $\mathrm{Ra}-226$ within their fecal matter. The specific fertilizers may provide supplements that allow the cattle to have stronger bones, thus not as much Ra-226 will be deposited within the cattle ultimately giving us a higher yield within the feces.

$\mathrm{Ra}-226$ deposits in bone and replaces calcium, bone irradiation of bone cells can lead to osteosarcomas through high exposure. Since calcium intake in children is more significant than adults, radiation exposure from fracking sites is more detrimental to child development. Additional symptoms that arise due to $\mathrm{Ra}-226$ exposure include anemia, cataracts, fractured teeth and death. Not only are these symptoms evident in humans, they are seen throughout non-human species that undergo irradiation [12].

Equipped with this information, further research into this area could divert attention towards developing legislation and instigating action towards hydraulic fracturing, which has accumulative effects.

\section{Conclusions}

The results from our proposal may confirm a significant difference between the biomagnification of Ra-226 across the agricultural ecosystem near fracking areas and non-fracking sites. The level of Ra-226 in cattle near fracking areas may reveal high levels of Ra-226 and as a result, the lifetime carcinogenic risk assessment can indicate high chances of developing cancer.

Equipped with this information, further remediation research could be done in order to determine efficient and effective methods to remove Ra-226 from domestic wells and thereby preventing radionuclides from entering the food chain. The ecosystem is interconnected and a change in the food and water humans consume can have detrimental effects, in this case cancer due to the biomagnification of Ra-226.

\section{List of Abbreviations}

EPA: United States Environmental Protection Agency

NORM: naturally occurring radioactive material

Ra-226: radium 226

\section{Conflicts of Interest}

The authors declare that they have no conflict of interests.

\section{Ethics Approval and/or Participant Consent}

None.

\section{Authors' Contributions}

SN: contributed to study design, developed all the figures, drafted the manuscript, and gave final approval of the version to be published.

BG: made contributions to study design, proposed the study's results based on current literature, discussed implications of the research and gave final approval of the version to be published.

PK: made contributions to the design of the study, drafted the manuscript, discussed implications of the research, and gave final approval of the version to be published. 
UNDERGRADUATE RESEARCH IN NATURAL AND CLINICAL SCIENCE AND TECHNOLOGY (URNCST) JOURNAL Read more URNCST Journal articles and submit your own today at: https://www.urncst.com

NE: contributed to design of the study, proposed the study's based on current literature, drafted the manuscript and gave final approval of the version to be published.

\section{Acknowledgements}

None.

\section{Funding}

This study was not funded.

\section{References}

[1] U.S EPA. Study of the potential impacts of hydraulic fracturing on drinking water resources. (2013). The Effects of Induced Hydraulic Fracturing on the Environment,141-228. https://doi.org/10.1201/b16342-10

[2] Almond, S., Clancy, S. A., Davies, R. J., \& Worrall, F. (2014). The flux of radionuclides in flowback fluid from shale gas exploitation. Environmental Science and Pollution Research,21(21), 12316-12324. https://doi.org/10.1007/s11356-014-3118-y

[3] Jodlowski, P., Macuda, J., Nowak J., Nguyen D. C. (2017). Radioactivity in wastes generated from shale gas exploration and production - North Eastern Poland. Journal of Environmental Radioactivity, 175-176. https://doi.org/10.1016/j.jenvrad.2017.04.006

[4] Brown, V. (2014). Radionuclides in Fracking Wastewater: Managing a Toxic Blend. Journal of Environmental Health Perspectives. https://doi.org/10.1289/ehp.122-A149.

[5] Warner, N. R., Christie, C. A., Jackson, R. B., \& Vengosh, A. (2013). Impacts of shale gas wastewater disposal on water quality in western Pennsylvania. En- vironmental Science \& Technology, 47(20), 11849. https://doi.org/10.1021/es402165b

[6] STYLE, F. T. O. (2005). Natural Resources Conservation Service Conservation Practice Standard.

[7] Thomas, P., Irvine, J., Lyster, J., \& Beaulieu, R. (2005). Radionuclides and trace metals in Canadian moose near uranium mines: comparison of radiation doses and food chain transfer with cattle and caribou. Health Physics, 88(5), 423-438. https://doi.org/10.1097/01.hp.0000154008.79474.d4

[8] Annamalai, S. K., Arunachalam, K. D., \& Selvaraj, R. (2017). Natural radionuclide dose and lifetime cancer risk due to ingestion of fish and water from fresh water reservoirs near the proposed uranium mining site. Environmental Science and Pollution Research, 24(18), 15427-15443. https://doi.org/10.1007/s11356-0179111-5

[9] Maxwell, S.L., Culligan, B.K., Warren, R.A., \& McAlister, D.R. (2016). Rapid method for the determination of 226Ra in hydraulic fracturing wastewater samples. Journal of radioanalytical and nuclear chemistry, 309(3), 1333- 1340. https://doi.org/10.1007/s10967-016-4745-1

[10] Tita, M., Ketney, O., \& Tita, O. (2012). Naturally occurring $137 \mathrm{Cs}, 90 \mathrm{Sr}$ and $226 \mathrm{Ra}$ radionuclides in raw milk in the Sibiu province of Romania. International Journal of Dairy Technology, 65(4), 511-515.

[11] U.S EPA. Framework for cumulative risk assessment. (2003). U.S. Environmental Protection Agency.

[12] Mills, M. N., \& Seifried, R. B. (2014). What is fracking wastewater and how should we manage it? Natural Resources \& Environment, 28(3), 9-14.

\section{Article Information}

Managing Editor: Jae Hyun Byun, Jeremy Y. Ng

Peer Reviewers: Patrick Diep, Joseph J. Kim

Article Dates: Received Jun 06 18; Accepted Oct 21 18; Published Dec 0618

\section{Citation}

Please cite this article as follows:

Naraentheraraja S, Gnanamanogaran B, Kapoor P, Eijaz N. Quantitative analysis of Ra-226 biomagnification near fracking sites: A research protocol. URNCST Journal. 2018 Dec 06: 2(12). https://urncst.com/index.php/urncst/article/view/62

DOI Link: https://doi.org/10.26685/urncst.62

\section{Copyright}

() Saranya Naraentheraraja, Bhairavei Gnanamanogaran, Paras Kapoor, Nayha Eijaz. (2018). Published first in the Undergraduate Research in Natural and Clinical Science and Technology (URNCST) Journal. This is an open access article distributed under the terms of the Creative Commons Attribution License (https://creativecommons.org/licenses/by/4.0/), which permits unrestricted use, distribution, and reproduction in any medium, provided the original work, first published in the Undergraduate Research in Natural and Clinical Science and Technology (URNCST) Journal, is properly cited. The complete bibliographic information, a link to the original publication on http://www.urncst.com, as well as this copyright and license information must be included. 


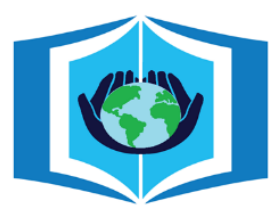

\section{URNCST Journal \\ "Research in Earnest"}

\section{Funded by the \\ Government of Canada}

\section{Canadằ}

Do you research in earnest? Submit your next undergraduate research article to the URNCST Journal!

| Open Access | Peer-Reviewed | Rapid Turnaround Time | International | | Broad and Multidisciplinary | Indexed | Innovative | Social Media Promoted |

Pre-submission inquiries? Send us an email at info@urncst.com | Facebook, Twitter and LinkedIn: @URNCST

Submit YOUR manuscript today at https://www.urncst.com! 